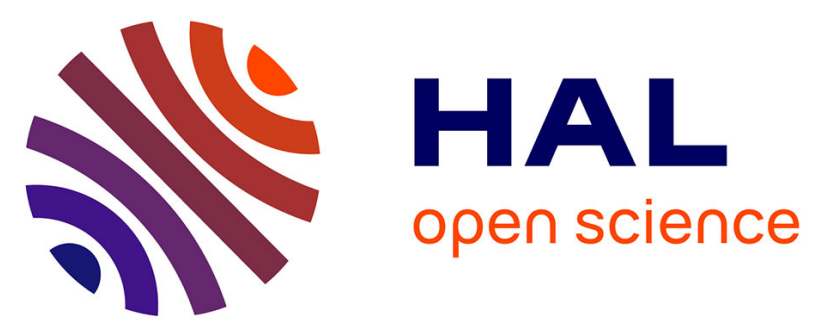

\title{
A New Mode of European Regulation? The Implementation of the Autonomous Framework Agreement on Telework in Five Countries
}

\author{
Trine P. Larsen, Søren Kaj Andersen
}

\section{> To cite this version:}

Trine P. Larsen, Søren Kaj Andersen. A New Mode of European Regulation? The Implementation of the Autonomous Framework Agreement on Telework in Five Countries. European Journal of Industrial Relations, 2007, 13 (2), pp.181-198. 10.1177/0959680107078252 . hal-00570961

\section{HAL Id: hal-00570961 \\ https://hal.science/hal-00570961}

Submitted on 1 Mar 2011

HAL is a multi-disciplinary open access archive for the deposit and dissemination of scientific research documents, whether they are published or not. The documents may come from teaching and research institutions in France or abroad, or from public or private research centers.
L'archive ouverte pluridisciplinaire HAL, est destinée au dépôt et à la diffusion de documents scientifiques de niveau recherche, publiés ou non, émanant des établissements d'enseignement et de recherche français ou étrangers, des laboratoires publics ou privés. 


\title{
Trine P. Larsen and Søren Kaj Andersen
}

University of Copenhagen, DENMARK

\section{A New Mode of European Regulation? The Implementation of the Autonomous Framework Agreement on Telework in Five Countries}

\begin{abstract}
This article examines the implementation of the first autonomous framework agreement signed by European social partners in a number of member states. Although the telework agreement states that it is to be implemented in accordance with national procedures and practices specific to management and labour, practice is often different. The approach adopted reflects the specific policy character of the telework agreement and the ongoing power struggle between unions, employers and the state. KEYWORDS: alternative regulation methods $\mathbf{e}$ autonomous agreements - Denmark, Sweden, Germany, Hungary and the UK - implementation - social dialogue
\end{abstract}

\section{Introduction}

Autonomous framework agreements between the European social partners are a new form of regulation through social dialogue. The first agreements on parental leave (1995), part-time work (1998) and temporary work (1999) were transposed into legally binding directives, but those on telework (2002) and work-related stress (2004) are to be implemented voluntarily at national level by the affiliates of the signatories. In this article, we argue that implementation has only partly followed what we normally consider the national 'practices and procedures specific to management and labour'. The choice of implementation method seems to be mainly determined by the specific policy type involved in the telework agreement, and the power struggle between unions, employers and the state.

We examine the implementation of the telework agreement in Denmark, Germany, Hungary, Sweden and the UK, very different labour market regimes within EU. We first briefly discuss contemporary theories on implementation before examining the extent to which the method of 
implementation and the procedures of negotiations and consultations have led to differences from the countries' traditional ways of regulating the labour market.

\section{Analytical Framework and Research Method}

Studies of the implementation of European regulations show that relatively new forms have been developed to transpose European policy into national practice (Falkner et al., 2005). Member states often choose different implementation methods according to the type of policy under consideration, for instance, legislation alone or in combination with collective agreements. The few studies of the implementation of sectoral agreements, recommendations and joint declarations signed by cross-sector organizations at European level suggest that national social partners often issue guidelines for good practice, or merely establish monitoring systems (Benedictus et al., 2002; Keller, 2005; Pochet, 2005). National social partners may involve local or federal authorities in some initiatives, for instance on vocational training, while excluding them from others.

The choice of implementation strategy seems to depend on three parameters: policy type, national regulation traditions for the labour market and power games between the actors (Falkner et al., 2005; Lampinen and Uusikylä, 1998; Rhodes, 2000). National regulation traditions are the rules of the game or institutionalized power balances which traditionally regulate national labour markets (Strøby-Jensen et al., 1996). Power games reflect short-term variations in the balance of power, and can emerge when implementing specific labour market reforms.

It is common to distinguish three types of labour market regime: liberalpluralist, neo-corporatist and state dominated (Crouch, 1993; Visser, 1996). We class Germany as a neo-corporatist regime while Denmark and to some degree Sweden display a mixture of neo-corporatist and pluralist traditions of regulation. In all three countries the labour markets are regulated primarily through collective agreements designed by relatively well-organized and strong trade unions and employers' associations. The UK is a pluralist regime, since the state has a limited role in regulating the labour market, while social partners are relatively weak and have no mandate to engage in national bargaining. The classification of Central and Eastern European labour market systems has been subject to much debate. Since Hungary has an extensive labour code and the social partners are relatively weak, we treat it as a variation of an etatistic regime.

The policy network theory of Rhodes and Marsh (1992) demonstrates the importance of power relations between government and key stakeholders when designing and implementing policy. Government dependence on key stakeholders, in this case social partners, can vary from one policy area 
to another; as a result, their participation in the political process differs according to the policy area under consideration (Rhodes, 2000; Rhodes and Marsh, 1992). However, stakeholders' collaboration, understanding and compliance with specific policy goals are crucial for the implementation results, especially when governments rely on private and voluntary entities to deliver their polices (Barrett and Fudge, 1981). The delegation of responsibility for the implementation telework agreement to the social partners rather than national governments may trigger new power games and forms of collaboration, since some member states have no tradition of leaving labour market regulation to social partners.

Various studies have shown that the policy type influences the choice of implementation method and the way key stakeholders are involved in the policy-making process (Larsen et al., 2006; Rhodes, 2000; Winter, 1994). We define this as the specific content, the implementation obligations and the responsibility for implementation prescribed by the agreement. One or more of these can be primarily influential according to circumstances, such as pressure from the EU, national or local levels.

We distinguish between three forms of negotiations and consultation procedures. Collective bargaining entails bipartite negotiations between the social partners (at confederal, sectoral or company level). Concertation involves tripartite negotiations between the state and the social partners. Consultation implies the exchange of different views, which do not necessarily result in common negotiations or a common decision (Ishikawa, 2003). With respect to national implementation methods, we differentiate between collective agreements, legislation and guidelines for good practice.

Our analysis is based on 16 interviews with representatives from national ministries, trade unions and employers' associations in Denmark, Germany, Sweden, Hungary and the UK conducted during the autumn 2005 and spring 2006. A further 125 interviews were conducted with representatives at sectoral level in Denmark, Germany and Sweden; because negotiations at sectoral level are rare in Hungary and the UK, we did not include the sector level in these countries. The interviews were by telephone or face-to-face. They were recorded and then transcribed. A common coding scheme was used to analyse the interviews. In the following analysis, we briefly describe the political process behind the telework agreement at European level before examining the detail of the implementation process at confederal and sectoral levels.

\section{Negotiating the Telework Agreement}

The telework agreement was signed by European social partners (ETUC, UNICE/UEAPME and CEEP) on 16 July 2002, after eight months of negotiations. It provided that teleworkers - defined as those who work 
away from the employer's premises regularly, and use information technology to do so - should possess the same rights as comparable workers at the employer's premises. The aim was to enable companies to modernize their work organization while assisting employees to reconcile work and family life. As far as possible, the use of telework was to be voluntary on both sides; there were provisions regarding health and safety and training; and measures were to be taken to avoid teleworkers becoming isolated from other employees. The European social partners and their member organizations were responsible for implementing and monitoring the agreement.

The European Commission first issued proposals for the regulation of telework in June 2000. Before the December 2001 Laeken Council, the European social partners had announced their intention to develop 'a spectrum of diversified instruments' as alternatives to the legislative route, including autonomous framework agreements (De Boer et al., 2005: 64). However, the use of this instrument for telework was highly controversial. UNICE, reflecting in particular the views of their British affiliate the Confederation of British Industry (CBI), at first opposed any form of regulation. CEEP was in favour of an autonomous agreement, but the ETUC was divided (Benedictus et al., 2002). Most Nordic affiliates supported an autonomous agreement, but the British Trades Union Congress (TUC) and some other continental unions argued in favour of a directive.

An important reason for agreement on this basis was that CEEP and UNICE would accept nothing more binding; but several interviewees also mentioned that the choice of regulation method reflected social partners' common wish to achieve increased autonomy from the European Commission and to show that they still had a role to play despite their failed attempt to reach an agreement on agency work. Country-specific interests were also important. Nordic unions in particular wanted to test the possibility of European regulation in a form consistent with their own 'voluntarist' principles; while southern European unions saw a voluntary agreement as an opportunity to strengthen their role in their national political systems. Telework was perceived as a relatively uncontroversial topic, of peripheral concern in most member states (EIROnline, 1998). 'Soft law' is seen as appropriate for subjects such as telework, which often concern the development of new practices and tools at company level rather than protecting employees' basic rights. The extent to which the policy type has also influenced the national implementation process is examined below.

\section{Implementing the Telework Agreement}

The agreement was to be implemented by 15 July 2005, but only five of the 25 member states (Italy, the Netherlands, Hungary, Spain and the UK) met this deadline (Clauwaert et al., 2005). Most others had nearly 
completed the implementation process, but some countries (Denmark, Austria, Czech Republic and Slovenia) had still not finalized implementation by mid-2006 and the position in two others (Lithuania and Cyprus) was unclear (ETUC/UNICE/CEEP/UEAPME, 2006). Failure to comply with EU implementation deadlines (even for binding directives) is not, however, a new phenomenon (Falkner et al., 2005; Mastenbroek, 2005).

A range of implementation methods has been used in different countries: legislation, collective agreements and guidelines for good practice (see Table 1). Portugal and several new member states have followed national traditions by transposing the telework agreement into legislation. The UK and Ireland have issued guidelines for good practice. Collective agreements or guidelines have been used in most other continental countries, though

TABLE 1. National Implementation Results

\begin{tabular}{|c|c|c|c|c|}
\hline & Legislation & $\begin{array}{l}\text { Collective } \\
\text { agreements/ } \\
\text { Framework } \\
\text { agreements }\end{array}$ & $\begin{array}{l}\text { Guidelines } \\
\text { for good } \\
\text { practice }\end{array}$ & $\begin{array}{l}\text { No informa- } \\
\text { tion regarding } \\
\text { the imple- } \\
\text { mentation } \\
\text { method }\end{array}$ \\
\hline $\begin{array}{l}\text { Nordic } \\
\text { countries }\end{array}$ & & $\begin{array}{l}\text { Denmark, } \\
\text { Sweden } \\
\text { Finland, } \\
\text { Norway }^{c} \\
\text { Iceland }^{c}\end{array}$ & $\begin{array}{l}\text { Sweden, } \\
\text { Denmark, } \\
\text { Norway }^{\mathrm{c}}\end{array}$ & \\
\hline $\begin{array}{l}\text { Continental } \\
\text { Europe }\end{array}$ & $\begin{array}{l}\text { Belgium, } \\
\text { Luxembourg }\end{array}$ & $\begin{array}{l}\text { Belgium, } \\
\text { France, } \\
\text { Germany, } \\
\text { Luxembourg, }\end{array}$ & $\begin{array}{l}\text { Germany, } \\
\text { Netherlands, } \\
\text { Austria }\end{array}$ & \\
\hline $\begin{array}{l}\text { Southern } \\
\text { Europe } \\
\text { Anglo-Saxon } \\
\text { countries }\end{array}$ & Portugal & $\begin{array}{l}\text { Italy, Spain, } \\
\text { Greece }\end{array}$ & $\begin{array}{l}\text { Spain } \\
\text { UK, } \\
\text { Ireland }\end{array}$ & \\
\hline $\begin{array}{l}\text { New member } \\
\text { states and } \\
\text { accession } \\
\text { countries }\end{array}$ & $\begin{array}{l}\text { Czech } \\
\text { Republic }{ }^{\text {a }} \\
\text { Hungary, } \\
\text { Slovakia, } \\
\text { Slovenia, } \\
\text { Estonia, } \\
\text { Poland, Malta }\end{array}$ & $\begin{array}{l}\text { Hungary, } \\
\text { Latvia } \\
\text { Poland }\end{array}$ & $\begin{array}{l}\text { Czech } \\
\text { Republic, } \\
\text { Latvia }\end{array}$ & $\begin{array}{l}\text { Bulgariab, } \\
\text { Cyprus }^{\text {Cyatiab }} \\
\text { Croat }^{b} \\
\text { Lithuania, } \\
\text { Turkey }^{b}\end{array}$ \\
\hline
\end{tabular}

Notes: ancertain whether telework is covered by existing legislation.

${ }^{b} \mathrm{New}$ candidate or accession countries.

${ }^{\mathrm{c}}$ Members of the European Economic Area who are obliged to implement the telework agreement.

Source: Clauwaert et al. (2005: 1); ETUC/UNICE/CEEP/UEAPME (2006: 5-10). 
regulating the labour market through such guidelines is not part of most national traditions, even though the telework agreement stated that implementation should be according to national 'practices and procedures specific to management and labour'. The experience in the five countries investigated also shows divergence between implementation method and national regulatory traditions.

\section{Denmark}

In Denmark, the government left the implementation of the telework agreement to the social partners, in line with its self-regulating principle and voluntary nature. The implementation process seems to follow national labour market traditions, where the social partners through collective bargaining largely determine the labour market regulation (Due et al., 1994). However, differences exist with respect to the way individual trade unions and employers associations at confederal and sectoral levels have addressed the implementation of the telework agreement.

At confederal level, the Ministry of Finance and Kommunernes Landsforening $(\mathrm{KL})$, representing employers within the state and local government sectors, and their union counterparts Central-organisationernes Fallesudvalg (CFU) and Kommunale Tjenestemend og Overenskomstansatte (KTO) agreed to include a reference to the European agreement in their existing framework agreements on tele- and homework. According to interviewees, this was decided because telework was already regulated in the Danish public sector. However, it is questionable whether this can be considered implementing the telework agreement by collective agreement.

In the private sector, some unions and employers' associations have relied on a similar procedure, while others have developed alternative methods or chosen not to implement the agreement at all. No agreement has been reached at confederal level, though negotiations are ongoing. The employers' confederation Dansk Arbejdsiverforening (DA) favours a set of guidelines for good practice, whereas the main union confederation Landsorganisationen $i$ Danmark (LO) argues that the agreement should be implemented as a collective agreement. The outcome remains uncertain. DA's resistance to negotiating an agreement was reinforced by the fact that other European countries with strong traditions of regulation by peak-level collective agreement developed guidelines for good practice rather than following their national traditions. The voluntary nature of the telework agreement has also, according to Danish interviewees, enabled DA to refuse to sign a collective agreement or develop guidelines for good practice with the professional confederation Akademikernes Centralorganisation (AC) (Kristiansen, 2003).

This implies that the policy type, particularly the self-regulating principle and legal status of the telework agreement, has triggered new power games 
between some trade unions and employers' associations and paved the way for alternative implementation methods at confederal level. This questions the force of Danish labour market traditions in this context.

At sectoral level, the great majority of private-sector unions and employers' associations have failed to implement the telework agreement. However, implementation agreements have been reached in two major sectors, manufacturing industry and commercial services; these have either replicated the European agreement in existing collective agreements, or used a similar method to the public sector. Affiliates of LO, DA and the white-collar confederation Funktionarerne og Tjenestemandenes Follesrad (FTF) have also relied on different implementation methods. In the private sector, only two affiliates of FTF and LO respectively have implemented the telework agreement, using guidelines for good practice or collective agreements. The sectoral unions and employers' associations cite a range of reasons for failure to implement the telework agreement in the private sector (see Table 2).

TABLE 2. Implementation Results in the Danish Private Sector

\begin{tabular}{|c|c|c|c|}
\hline & DA & LO & FTF \\
\hline Affiliates & 13 & 18 & 98 \\
\hline $\begin{array}{l}\text { Implementation } \\
\text { record }\end{array}$ & $\begin{array}{l}\text { Collective } \\
\text { agreements: } 1 \\
\text { Guidelines: } 2\end{array}$ & $\begin{array}{c}\text { Collective } \\
\text { agreements: } 8^{\text {a }} \\
\text { Guidelines: } 1\end{array}$ & $\begin{array}{c}\text { Collective } \\
\text { agreements: } 67^{2} \\
\text { Guidelines: } 1\end{array}$ \\
\hline \multicolumn{4}{|l|}{$\begin{array}{l}\text { Reasons for } \\
\text { non-compliance }\end{array}$} \\
\hline $\begin{array}{l}\text { No need to } \\
\text { regulate telework }\end{array}$ & 7 & 8 & 10 \\
\hline $\begin{array}{l}\text { Telework } \\
\text { irrelevant }\end{array}$ & 1 & 7 & 3 \\
\hline $\begin{array}{l}\text { Existing } \\
\text { guidelines/ } \\
\text { agreements }\end{array}$ & 3 & 3 & 11 \\
\hline No request & 6 & 5 & 5 \\
\hline $\begin{array}{l}\text { Unwilling } \\
\text { Employers }\end{array}$ & - & 2 & 1 \\
\hline Unawareness & 1 & 1 & 4 \\
\hline $\begin{array}{l}\text { No mandate/lack } \\
\text { resources }\end{array}$ & 1 & - & 2 \\
\hline Feel no obligation & 2 & 5 & 5 \\
\hline Don't know & 3 & 2 & 13 \\
\hline
\end{tabular}

Notes: Different member organizations mentioned a range of reasons why they had not implemented the telework agreement, which is why the numbers of answers given and the number of member organizations are not the same. aprimarily members in the public sector. 
In most cases, they already regulated telework by collective agreement, or else thought that the issue was irrelevant to their members because of the nature of their work. Hardly any unions or employers' associations had been asked by their members or counterparts to implement the telework agreement. A few interviewees also claimed that they lacked competence to sign a collective agreement on the issue, or stated that their employer counterparts had been unwilling to implement the agreement. Other unions and employers' associations also reported that they felt no obligation to implement the agreement because it was voluntary. This suggests that the policy type, particularly the agreement's content and legal status have been crucial for the implementation record at sectoral level. As a result, the influence of Danish regulatory traditions seems limited. This tends also to be the case when telework was regulated by collective agreement; some respondents still argued that collective agreements were not always their preferred implementation method, although they generally speaking supported the Danish collective agreement model. Employers in particular reported that the content of the telework agreement and, in particular its consistency with existing Danish rules, largely determined their choice of implementation method.

In sum, the Danish case suggests that the policy type has triggered new power games among social partners and paved the way for alternative implementation methods which deviate from what we normally define as Danish labour market traditions. As explained below, Denmark is not the only country which has relied on alternative implementation methods.

\section{Germany}

The German social partners have also relied on a mix of implementation methods ranging from collective agreements, joint declarations, guidelines for good practice to information pamphlets about the telework agreement. These methods differ to some extent from what we normally associate with German labour market traditions, and this is even more marked when looking at the implementation method used by individual trade unions and employers associations.

At confederal level, the social partners within the public and private sectors have relied on different implementation methods. The privatesector employers' confederation Bundesvereinigung der Deutschen Arbeitgeberverbände (BDA) signed a joint declaration with the union confederation Deutscher Gewerkschaftsbund (DGB), encouraging social partners at sectoral and company levels to implement the agreement. These organizations also held a conference with their counterparts from Austria, Denmark and France, and published a pamphlet with guidelines for good practice (BDA/ZDH/VKA/DGB, 2006). The confederation of artisan producers Zentralverband des Deutschen Handwerks (ZDH) simply 
informed members about the telework agreement, while the peak organizations in the public sector failed to implement the agreement because they had no mandate to sign collective agreements. The civil service confederation Deutscher Beamtenbund (DBB) is not a member of ETUC and felt no obligation to implement the agreement.

The interviewees from BDA and DGB also emphasized that they had no mandate to negotiate collective agreements, but this was only part of the reason why they chose to regulate telework through guidelines for good practice. The content of the telework agreement is already regulated through existing German legislation and the peak organizations therefore found it unnecessary to transpose the agreement into legislation. In addition, its legal status and self-regulating principle induced them to use guidelines for good practice, as the only option when the implementation responsibility lies with the national social partners and the agreement is voluntary. The implementation responsibility given to the peak organizations has also instigated a relatively new form of social dialogue between them, since they rarely collaborate on developing common policy according to the German interviewees. This suggests that the policy type has largely determined the choice of implementation method as well as the procedures for negotiation at confederal level in Germany. Some peak organizations have largely been able to ignore the agreement while others have developed alternative implementation methods.

Most German trade unions and employers associations at sectoral level have thus failed properly to implement the telework agreement. In the public sector, the local authority employers (Vereinigung der kommunalen Arbeitgeberverbände, $\mathrm{VkA}$ ) has signed local agreements which cover approximately 10,000 employees, but the Ministry of the Interior and the Tarifgemeinschaft deutscher Länder (TdL), representing the federal and Land-level employers, have failed to implement it (BDA/ZDH/VKA/ DGB, 2006). Likewise, relatively few trade unions and employers' associations have implemented the telework agreement in the private sector. BDA's affiliate Gesamtmetall is the main exception, having signed local agreements and guidelines with their counterpart IG Metall. BDA's member organization, the Employers Association of Insurance companies $(\mathrm{AGV})$, has also signed some local agreements and guidelines with their local counterparts. The private-sector put forward a range of explanations (see Table 3).

As in Denmark, most found it unnecessary to implement the telework agreement. Few local and sectoral organizations already regulated telework through collective agreements or guidelines, but the vast majority saw regulations on telework as irrelevant for their own members. Several union and employer representatives also reported that neither their members nor counterparts had requested them to regulate telework as a result of the European agreement. This suggests that the content of the agreement 
TABLE 3. Implementation Results in the German Private Sector

\begin{tabular}{|c|c|c|}
\hline & $\mathrm{BDA}$ & DGB \\
\hline Affiliates & 54 & 8 \\
\hline Implementation record & $\begin{array}{c}\text { Collective } \\
\text { agreements: } 2 \\
\text { Guidelines: } 2\end{array}$ & $\begin{array}{c}\text { Collective } \\
\text { agreements: } 2^{\mathrm{a}} \\
\text { Guidelines: } 2^{\mathrm{a}}\end{array}$ \\
\hline \multicolumn{3}{|l|}{ Reasons for non-compliance } \\
\hline No need to regulate telework & 8 & 3 \\
\hline Telework irrelevant & 23 & 4 \\
\hline $\begin{array}{l}\text { Existing } \\
\text { guidelines/agreements }\end{array}$ & 12 & 1 \\
\hline No request & 15 & 3 \\
\hline Unwilling employers & - & - \\
\hline Unawareness & 8 & 1 \\
\hline No mandate/lack resources & - & - \\
\hline Feel no obligation & 6 & - \\
\hline Don't know & 20 & 2 \\
\hline
\end{tabular}

Note: Different member organizations mentioned a range of reasons as to why they had not implemented the telework agreement, which is why the numbers of answers given and the number of member organizations are not the same.

${ }^{a}$ only some members at local level.

to some extent accounts for the relative poor implementation record. However, some organizations also stated that they were unaware of the telework agreement and some also felt no obligation to implement it because of its voluntary nature. Thus the German case also suggests that it is particularly the policy type which has paved the way for alternative regulation methods, even in a country where legislation and collective agreements are the most common forms of labour market regulations (Marginson, 2005).

\section{Sweden}

The social partners have taken the lead in the implementation process in Sweden, using collective agreements and guidelines at confederal and sectoral levels. The peak organizations held a series of meetings, and in December 2005 agreed on a common set of guidelines for good practice on telework for both the public and private sectors, which stands in sharp contrast to the cases of Germany and Denmark. The negotiation procedures for the telework agreement were, according to the Swedish interviewees, relatively novel, since employment issues are primarily regulated through collective agreements at sectoral level, while European labour market directives tend to be implemented by legislation. The negotiation procedures and 
implementation methods were also subject to much debate. The three trade union confederations wanted to regulate telework according to Swedish traditions of collective agreements, while the private employers (Svenskt Näringsliv, SN) in particular opposed this, arguing that autonomous agreements signed by European social partners represented a new form of regulation for which Sweden had no precedent (Ahlberg, 2002). The unions were forced to settle for guidelines which encourage rather than compel social partners at sectoral level to implement the agreement, since SN was unwilling to alter its position. This suggests that new power games have to some extent been triggered at confederal level by the policy type under consideration. These new power games seem to have been more influential than Swedish regulatory traditions.

Such power games seem to have played only a limited role at sectoral level, although a recent report by the white-collar confederation Tjänstemännens Centralorganisation (TCO) concluded that unwilling employers had forced their affiliates to regulate the European agreement through guidelines rather than collective agreements (TCO, 2005). However, only one trade union at sectoral level mentioned this during the interviews. Instead, the content of the telework agreement seems to explain why the majority of Swedish trade unions and employers' associations failed to implement it in the private sector; while social partners in the public sector decided to add a reference to the European agreement in their existing collective agreement on telework.

Representatives from both sides of industry referred to this factor as the main reason for their preferred implementation method. The publicsector representatives stated that they already regulated telework through collective agreements, but as in the Danish case, it is debatable whether adding a reference rather than replicating the European agreement in their collective agreements can be considered as proper implementation. Table 4 shows the number of organizations who have implemented the telework agreement at sectoral level and the main arguments put forward by those that failed to do so.

Among interviewees at sectoral level, eight TCO affiliates in the public sector had transposed the telework agreement into collective agreements. In the private sector, the employers' associations for forestry and farming and their counterpart the white-collar union (HTF) were the only member organizations of TCO and SN to implement the telework agreement through collective agreements, though guidelines for good practice were agreed in three sectors. Among affiliates of the largest (manual workers') confederation, Landsorganisationen i Sverige (LO), the metal workers' union also agreed on guidelines for good practice with the employers. Hence national regulatory traditions have only to some extent been followed at sectoral level, although Sweden has strong traditions of collective bargaining. 
TABLE 4. Implementation results in the Sweden private sector

\begin{tabular}{|c|c|c|c|}
\hline & SN & $\mathrm{LO}$ & $\mathrm{TCO}$ \\
\hline Affiliates & 50 & 15 & 17 \\
\hline $\begin{array}{l}\text { Implementation } \\
\text { record }\end{array}$ & $\begin{array}{c}\text { Collective } \\
\text { agreements: } 1 \\
\text { Guidelines: } 4\end{array}$ & $\begin{array}{c}\text { Collective } \\
\text { agreements: } \\
\text { Guidelines: } 1\end{array}$ & $\begin{array}{c}\text { Collective } \\
\text { agreements: } 9^{\mathrm{a}} \\
\text { Guidelines: } 3\end{array}$ \\
\hline \multicolumn{4}{|l|}{$\begin{array}{l}\text { Reasons for } \\
\text { non-compliance }\end{array}$} \\
\hline $\begin{array}{l}\text { No need to } \\
\quad \text { regulate telework }\end{array}$ & 3 & 5 & 1 \\
\hline $\begin{array}{l}\text { Telework } \\
\text { irrelevant }\end{array}$ & 12 & 3 & 8 \\
\hline $\begin{array}{l}\text { Existing } \\
\text { guidelines/agreements }\end{array}$ & 4 & 1 & 3 \\
\hline No request & 13 & 6 & 1 \\
\hline $\begin{array}{l}\text { Unwilling } \\
\text { employers }\end{array}$ & - & - & 1 \\
\hline Unawareness & 4 & 3 & 1 \\
\hline $\begin{array}{l}\text { No mandate/lack } \\
\text { resources }\end{array}$ & 2 & - & - \\
\hline Feel no obligation & 1 & - & - \\
\hline Don't know & 23 & 4 & 5 \\
\hline
\end{tabular}

Note: Different member organizations mentioned a range of reasons as to why they had not implemented the telework agreement, which is why the numbers of answers given and the number of member organizations are not the same.

${ }^{a}$ primarily members in the public sector.

Source: ETUC/UNICE/CEEP/UEAPME (2006).

The most common explanations put forward by Swedish social partners for their limited implementation of the telework agreement were that their members or counterparts had not requested this, and that telework was irrelevant for their members. Some unions and employers' associations even reported that their organization had removed previous regulations on telework from their collective agreements because their members were not interested in working from home. This implies that in Sweden too, the content of the telework agreement played an essential role for the choice of implementation method. However, some interviewees also reported that they were unaware of the telework agreement and that they had limited competences to sign sectoral agreements. A mix of factors seems therefore to have influenced the relatively poor implementation record in Sweden. As a result, the Swedish regulatory traditions seem to have had a limited influence on the implementation process. 


\section{The UK}

In contrast to Denmark, Sweden and Germany, the British implementation process has involved both social partners and the government. The TUC and CBI took the lead in developing guidelines, while the government provided mediation, funding and monitoring. This form of implementation is relatively novel in the UK, as the British government has been involved in a negotiation process which deviates from the dominance of company-level bargaining between unions and employers (Edwards et al., 1998). Tripartite negotiations, where social partners take the lead, are also relatively unusual in the British political system, where governments usually possess an overall parliamentary majority and can implement labour market reforms unilaterally (Taylor-Gooby, 2001). According to the British interviewees, the relatively new policy style has been triggered by the telework agreement's voluntary nature and self-regulating principle. The British government therefore found it unnecessary to legislate, but participated in the negotiations after receiving an invitation from the TUC and CBI.

The British interviewees also reported that it was mainly the CBI's initiative to invite the government to host the negotiations. It feared that bipartite negotiations with the TUC would signal its acceptance of social partnership and collective bargaining at confederal level, which it fundamentally opposes. However, it is noticeable that CBI was eventually willing to negotiate with the TUC. According to the interviewees, it could hardly reject implementing the telework agreement, even though this required negotiation with the TUC, since the voluntary nature of the telework agreement reflected its own arguments for less EU legislation. This suggests that European pressure in terms of introducing a new form of European regulation has paved the way for a relatively new British negotiations procedure.

The policy type (particularly the telework agreement's self-regulating principle) seems important in this respect, although ongoing power games also influenced the British choice of negotiation form. It should be noted, however, that these negotiations coincided with those over the implementation of the 2002 EU information and consultation directive, which resulted for the first time on a negotiated agreement for transposing EU employment legislation in the UK. The influence of national labour market tradition on the implementation process therefore seems limited. This is further underpinned when examining the social partners and the British government's arguments for regulating telework through guidelines for good practice.

The British government and social partners found it unnecessary to transpose the telework agreement into legislation, but they initially disagreed that guidelines were the right instrument. The TUC called for a collective agreement, mainly because teleworkers were to a large extent 
already protected by existing labour laws, and the European agreement was more about developing new forms of organizing work than securing individual employees' rights. The government put forward similar arguments for their choice of guidelines, while the CBI advocated guidelines as consistent with British regulatory traditions and their wish for a flexible implementation method. This indicates that the telework agreement's content and voluntary nature influenced the choice of British implementation method. Hence the negotiation process also suggests that ongoing power games between social partners and government have affected the implementation process.

During the negotiations, the CBI reportedly pressurized the TUC to sign the proposed guidelines by threatening to leave the negotiations. Interviewees also reported that the British government had strongly supported the CBI position and had threatened the TUC with exclusion from other policy areas unless they accepted the proposed guidelines for good practice. It was mainly to avoid stalemate and exclusion that TUC very reluctantly signed the guidelines. We conclude that the policy type seemed to have triggered new power games between the national government and social partners, which largely determined the policy outcome at confederal level.

The extent to which the telework agreement has been transposed at sectoral and local levels in the UK is uncertain, but according to the British interviewees, no sectoral agreement has so far been signed - to be expected, because of the limited tradition of collective bargaining at sectoral level and none of the interviewees knew the exact number of local agreements on telework. In sum, the British implementation process indicates that the policy type has to some extent triggered new power games and influenced the choice of implementation method in the UK, although national traditions have to some extent been followed.

\section{Hungary}

Not all countries have developed alternative implementation methods for the telework agreement. Hungary, for instance, has followed their national traditions and in May 2004 transposed the telework agreement into legislation, which gives precedence to collective agreements on telework signed at sectoral level.

During the implementation process, the government took the lead, in sharp contrast to the implementation process in the other four countries. According to the Hungarian interviewees, the social partners have primarily contributed to the process through consultation, but generally speaking supported the government's proposed implementation method. However, some interest organizations, trade unions and employers' associations opposed such a rigid form of regulation. 
The main arguments put forward by the social partners and the government concerned the relative weakness of social dialogue at confederal and sectoral level. According to the Hungarian interviewees, the social partners had themselves proposed that telework be regulated through legislation, as they lacked the resources in terms of legal expertise to transpose the agreement into collective agreements. The government referred to the relatively weak positioning of social partners in Hungary as their main argument for legislation (EIROnline, 2004). In Hungary, union density is about 20 percent and unions are often not present in companies with fewer than 10 employees, which is the most common company size (DTI, 2006; StrøbyJensen, 2005). The implicit power relations between social partners and national government seem therefore to be an important reason why legislation regulates telework in Hungary. The policy-making process further underpins this, as the contributions from social partners were limited during the consultation process, mainly because of their relatively few resources and low interest in telework. The latter reason also suggests that the telework agreement's content to some extent influenced the choice of implementation method. The government's existing plans on regulating telework through legislation may also have influenced the choice of implementation method. According to the Hungarian interviewees, telework had for years been a high-profile issue on the government's political agenda, since it was seen as a way to increase the employment rate.

In sum, the Hungarian implementation process indicates that the social partners' meagre resources and low union density, along with the relative weak social dialogue, have been crucial for the decision to regulate telework through legislation. This suggests that the European agreement's voluntary nature and self-regulating principle had only a limited effect on the Hungarian implementation process.

\section{Discussion and Conclusion}

The European social partners' first autonomous framework agreement on telework has recently been transposed into national practices across Europe. The implementation process has been rather patchy, as a range of industrial relations scholars predicted already in the 1990s (Keller and Sörries, 1999; Streeck, 1994). Most scholars and even the European social partners themselves, in their latest evaluation report on the telework agreement, refer to the member states' industrial relations systems as the main reason for the diverse implementation results. However, in our study we have identified three parameters, which to a varying degree influenced the choice of implementation method and procedures for negotiation and consultation; national regulation traditions, ongoing power games and the policy type. 
National labour market traditions seem to have an uneven influence on the implementation process, even in countries with strong traditions of collective bargaining (Denmark, Sweden and Germany) and where policymakers decided to follow national traditions (Hungary, the UK and to some extent Denmark). The ongoing power games (the balance of power between social partners and the state during the implementation of a specific policy) seem to have played a more substantial role in the implementation process. Likewise, the policy type was also crucial for the implementation process. This concept refers to three elements; the content of the agreement, the implementation obligations and the delegation of the implementation responsibility to national social partners rather than national governments.

It was particularly the voluntary nature of the telework agreement, its content and self-regulating principle which paved the way for alternative implementation methods and procedures for negotiations and consultations. Some member states have no tradition of leaving labour market regulation to social partners, which meant that new power games between social partners and the state often were instigated. Our approach goes beyond the arguments for path-dependency and the power resource model of Rhodes and Marsh (1992), since some national employers' associations have been engaged in a form of social dialogue with their counterpart, even though they often oppose any collaboration with trade unions at confederal level. In addition, some member states have developed alternative implementation methods because of the telework agreement's content and voluntary nature, sometimes giving rise to new power struggles between employers, unions and the state.

As a result, the implementation record of the selected countries suggests that the telework agreement has most often been transposed at confederal level, often through the development of alternative implementation methods and procedures for negotiation and consultation. These approaches commonly deviate from national regulatory traditions. At confederal level, Germany, Sweden and in part Denmark have developed alternative implementation strategies through bipartite bargaining processes (Germany, Denmark) or common negotiations including all peak organizations (Sweden). The UK has relied on concertation at confederal level while in Hungary the government has engaged in consultation before enacting legislation. The approach in the UK is relatively novel, since the social partners took the lead in the implementation process, while the government had a more passive role. At sectoral level, the social partners have often failed to transpose the telework agreement in accordance with national practice in all five countries. The different country studies questions the notion of path dependency: even when European policies specifically encourage member states to follow national practices and procedures specific to management and labour, the procedures actually adopted have often proved to be very different. 


\section{ACKNOWLEDGEMENTS}

The article is part of a five year research programme Social Dialogue in the Enlarged $E U$ funded by the Danish Industry's Educational Fund (Industriens Uddannelsesfond), the Ministry of Employment (Beskaftigelsesministeriet), the Confederation of Danish Employers (Dansk Arbejdsgiverforening) and the Building Society's Educational Fund (Byggeriets uddannelsesfond). We thank the different representatives of national social partners and policy-makers who participated in this study, and our colleagues Christina J. Colclough for useful comments on an earlier draft and Åsa Lundkvist for transcribing the Swedish interviews.

\section{REFERENCES}

Ahlberg, K. (2002) 'Först Frivilliga Europeiska Avtalet ny Norm för Umgänget mellan Parterna?', EU og Arbetsrätt 2: 4-5.

Barrett, S. and Fudge, C. (eds) (1981) Policy and Action. London: Sage.

$\mathrm{BDA}, \mathrm{ZDH}, \mathrm{VKA}$ and DGB (2006) Joint Report on Implementation of the

European Framework Agreement on Telework. Berlin: BDA.

Benedictus, H., De Boer, R., van der Meer, M., Salverda, W., Visser, J. and Zijl, M. (2002) The European Social Dialogue: Development, Sectoral Variation and Prospects, Report to the Ministry of Social Affairs and Employment. Amsterdam: AIAS.

Clauwaert, S., Düvel, W. and Schömann, I. (2005) Report on the Implementation of the ETUC/UNICE-UEAPME/CEEP Framework Agreement on Telework, Executive Summary. Brussels: ETUI.

Crouch, C. (1993) Industrial Relations and European State Traditions. Oxford: Clarendon Press.

De Boer, R., Benedictus, H. and van der Meer, M. (2005) 'Broadening without Intensification: The Added Value of European Social and Sectoral Dialogue', European Journal of Industrial Relations 11(1): 51-70.

DTI (2006) Report of UK Presidency Conference: European Social Dialogue, Many Voices, Common Vision. London: DTI.

Due, J., Madsen, J.S. and Strøby Jensen, C. (1994) The Survival of the Danish Model. Copenhagen: Jurist- og Økonomforbundets forlag.

Edwards, P., Hall, M., Hyman, R., Marginson, P., Sisson, K., Waddington, J. and Winchester, D. (1998) 'Great Britain: from Partial Collectivism to Newliberalism to Where?', in A. Ferner and R. Hyman (eds) Changing Industrial Relations in Europe, pp. 1-54. Oxford: Blackwell.

EIROnline (1998) 'Teleworking and Industrial Relations in Europe', available online at: [http://www.eurofound.europa.eu/eiro/1998/11/study/ tn9811201s.html].

EIROnline (2004) 'New Legislation Regulates Telework', available online at: [http://www.eurofound.europa.eu/eiro/2004/10/feature/hu0410101f.html].

ETUC, UNICE, CEEP and UEAPME (2006) 'Implementation of the European Framework Agreement on Telework', available online at: [http://ec.europa.eu/ employment_social/news/2006/oct/telework_implementation_report_en.pdf].

Falkner, G., Treib, O., Hartlapp, M. and Leiber, S. (2005) Complying with Europe. Cambridge: Cambridge University Press. 
Ishikawa, J. (2003) Key Features of National Social Dialogue: A Social Dialogue Resource Book. Geneva: ILO.

Keller, B. (2005) 'Europeanisation at Sectoral Level', Transfer 11(3): 397-408.

Keller, B. and Sörries, B. (1999) 'The New European Social Dialogue: Old

Wine in New Bottles', Journal of European Social Policy 9(2): 111-25.

Kristiansen, J. (2003) Redegørelse om gennemførelse af rammeaftalen om telearbejde, Notat til AC. København: AC.

Lampinen, R. and Uusikylä, P. (1998) 'Implementation Deficit: Why Member States Do Not Comply with EU Directives', Scandinavian Political Studies 21(3): 231-50.

Larsen, T.P., Taylor-Gooby, P. and Kananen, J. (2006) 'New Labour's Policy Style: A Mix of Policy Approaches', Journal of Social Policy 35(4): 629-49.

Marginson, P. (2005) 'Europeanisation and Regime Competition: Industrial Relations and EU Enlargement', Industrielle Beziebungen 13(3): 1-21.

Mastenbroek, E. (2005) 'EU Compliance: Still a Black Hole', Journal of European Public Policy 12(6): 1103-20.

Pochet, P. (2005) 'Sectoral Social Dialogue? A Quantitative Analysis', Transfer 11(3): 313-33.

Rhodes, R.A.W. and Marsh, J. (1992) 'New Directions in the Study of Policy

Networks', European Journal of Political Research 21: 181-205.

Rhodes, R.A.W. (ed.) (2000) Transforming British Government. London: Macmillan Press.

Streeck, W. (1994) 'European Social Policy after Maastricht: The Social

Dialogue and Subsidiarity', Economic and Industrial Democracy 15, 151-77.

Strøby-Jensen, C. (2005) 'Svage og stærke fagforeninger', Samfundsøkonomen 4: $20-42$.

Strøby-Jensen, C., Lubanski, N. and Andersen, S.K. (1996)

Arbejdsmarkedsmodeller i Europa. København: Jurist- og Økonomforbundets forlag.

Taylor-Gooby, P. (ed.) (2001) Welfare States under Pressure. London: Sage.

TCO (2005) The Implementation in Sweden of the Framework Agreement on Telework, Report from TCO. Stockholm: TCO.

Winter, S. (1994) Implementering og Effektivitet. Herning: Forlaget Systime A/S. Visser, J. (1996) 'Traditions and Transitions in Industrial Relations: A European View', in J.V. Ruysseveldt and J. Visser (eds) Industrial Relations in Europe: Traditions and Transitions, pp. 1-41. London: Sage.

TRINE P. LARSEN is Research Assistant at FAOS, University of Copenhagen and doctoral student at the University of Kent at Canterbury, UK.

ADDRESS: FAOS, Sociologisk Institut, Øster Farimagsgade 5, Postboks

2099, 1014 København K, Denmark. [e-mail: tpl@faos.dk]

SØREN KAJ ANDERSEN is Associate Professor at FAOS,

University of Copenhagen. 